\title{
Mitigation of Hospital Acquired Infections in Developing Countries through the Provision of a Better IAQ
}

\author{
M. N. N. Rodrigo, Y. Kosala, B. A. K. S. Perera and Chandana Dalugoda
}

\begin{abstract}
Indoor Air Quality (IAQ) determines the functionality and economics of a building. Thus, healthcare facilities are under pressure to maintain good IAQ as many people are at risk because of the infectious diseases that can spread through air quite easily. When infections caught by hospitalized patients are not controlled, Hospital Acquired Infections (HAIs) could develop. HAIs relate to those infections that are not present at the time of admission of a patient but which develop during the course of his/her stay at hospital. HAIs directly affect patients, their caretakers and employees. Hence, the healthcare sector is highly concerned about IAQ since airborne microorganisms present in indoor air can cause HAIs. In this study, a qualitative approach was used with semistructured interviews and a documentary review to collect data from three identified cases. Resulting findings were validated by four experts. Initially, the importance of IAQ in the healthcare sector was identified through semi-structured interviews. Sources affecting IAQ such as human activities, equipment etc., were recognized from the literature survey and validated through semi-structured interviews. Consequently, the impact and causes of HAIs like inadequate ventilation, poor hand hygiene, poor housekeeping etc., were investigated and a framework to assist in mitigating HAIs by improving IAQ was proposed.
\end{abstract}

Keywords: Indoor Air Quality (IAQ), Healthcare Facilities, Hospital Acquired Infections (HAI), Occupant's Health, Infection Control

\section{Introduction}

Indoor Air Quality (IAQ) is one of the major factors that determine the functionality and economics of a building [3]. Quality air is a fundamental and important aspect of people's health and well-being and is significant from both social and economic points of view [9]. Nowadays, the majority of the people stay indoors approximately $90 \%$ of their time exposing themselves more to the inside atmosphere than to the outside atmosphere [31]. Kubba [7] has stated that IAQ is interrelated to occupants' health since there is a tendency for health threats to arise when air consists of pollutants such as biological contaminants, chemicals, particles and aerosols which lead to headaches, fatigue, respiratory problems, and irritations or allergies of the nose, eyes and throat.

Healthcare facilities are under pressure to maintain superior IAQ as a large number of people are at risk including post-operative patients, immune compromised patients, seniors and infants [34]. Air is one of the mediums that transmit infections which can also be contracted through direct contact [26]. A healthcare facility is one of the most critical places for infections through which a countless number of sicknesses are caused to patients [4].
Ducel et al. [5] have declared that if the infections caught by hospitalized patients are not controlled, it will lead to the development of Hospital Acquired Infections (HAIs). Moreover, HAIs affect the patients and the management in many ways. On the other hand, pollutants and their emission sources differ from building to building because of their dependence on the functionality and the usage of the building [1].

Research on IAQ issues in buildings such as office complexes, commercial buildings, schools and those in the apparel industry have already been conducted. A few cited literatures clearly

Miss. M.N.N. Rodrigo, B.Sc.(Hons) in Quantity Surveying, Lecturer, University of Moratuwa.

Email:navomail@gmail.com

Miss. Y. Kosala, B.Sc.(Hons) in Facilities Management,

Executive Facilities Manager, Sri Lanka Technological Campus.

Email:ykosala@gmail.com

Prof. B.A.K.S. Perera, B.Sc.(Hons) in Quantity Surveying,

M.Phil in Building Economics, FIQSSL, FAIQS, FRICS,

ICECA, Professor in Quantity Surveying, University of

Moratuwa.

Email:pererabaks@gmail.com

Eng. Chandana Dalugoda, MIE, MCIBSE, ASHRAE,

GCGI, MConsE (SL), Chartered Engineer, Certified

Building Services Engineer, ASHRAE Distinguished

Lecturer, Managing Partner/Senior Consultant, Chandana

Dalugoda Consultants.

Email:chandana_cnd@sltnet.lk 
indicate that IAQ is an important issue in hospitals which has to be considered in creating a healthy and infection free environment to patients and a safe working environment for the staff (Ramasamy et al. [36]). EMH magazine has mentioned that HAIs kill more people in the United States compared to AIDS, breast cancer and automobiles [32].

Even though airborne transmission is one of the main routes that spread germs in the healthcare facilities giving rise to HAIs, it has not been sufficiently studied [24]. There is a necessity to maintain proper IAQ in private healthcare facilities to mitigate HAIs. Thus, the research aim was to identify the strategies that will enhance the IAQ in private healthcare facilities and safeguard the well-being of their users by mitigating HAIs. In order to achieve the aim of this research, the importance of IAQ, sources and effects of IAQ in healthcare facilities, causes of HAIs and their impact were initially identified. Subsequently, the existing practices that are being followed to maintain a good IAQ in the Sri Lankan healthcare facilities were investigated and a framework was proposed to manage IAQ in healthcare facilities towards mitigating HAIs.

\section{Literature Review \\ 2.1 Indoor Air Quality}

Indoor Air Quality (IAQ) is a term that refers to the air quality within and around buildings, especially when it has an effect on the health and comfort of building occupants (Lawrence et al. [21]). According to ASHRAE [2], indoor air that has acceptable good quality will not contain any known contaminants at concentrations identified by cognizant authorities as harmful and a significant majority ( $80 \%$ or more) of people exposed to it will not express dissatisfaction with it. IAQ refers to the nature of the conditioned air that is circulated throughout a space where people work and live, for enhancing the occupants' health, comfort and also workplace productivity [15].

U.S. Environmental Protection Agency [11]; Anon [13]; and Levin [8] have identified outdoor air quality; HVAC systems; building and furnishing materials; and human occupants and their activities as sources of indoor air pollutants. These sources cause the sick building syndrome and other building related illnesses [28]. Although these sources are common in all buildings, they are relatively more important in healthcare facilities as they can lead to hospital acquired infections.

\subsection{Hospital Acquired Infections}

Hospital Acquired Infections (HAIs) by definition relate to the infections that do not exist at the time of admission of the patient concerned to the hospital but which are developed during the course of their stay in the hospital [22]. The Center for Disease Control and Prevention (CDC) has estimated that 1 out of 20 healthcare patients will contract a HAI and that airborne diseases account for up to 33 percent of all HAIs with overall direct medical costs incurred by hospitals related to HAIs ranging from $\$ 28-45$ billion per year [33]. Likewise, $8-12 \%$ of patients in acute care hospitals in developed countries contract some form of infection from hospitals [27]. Patients stay indoors up to 22 hours a day and because of their long periods of exposure to indoor air of poor quality, they have a higher risk of being exposed to adverse health effects (Bernstein et al. [14]). When a patient has been admitted to a hospital for reasons other than an infection, these infections will occur within 48 hours after admission or 3 days after discharge or 30 days after an operation (Inweregbu et al. [18]). Liyanage and Egbu [22] and Codinhoto et al. [16] have stated that HAIs directly affect the patient, their caretakers and employees through severe or chronic illnesses, pain, anxiety, depression and the need to stay longer in the hospital. It is found that the healthcare sector is highly concerned about IAQ since airborne microorganisms present in indoor air within hospitals can cause HAIs.

IAQ is a significant problem in the healthcare sector where air quality is likely to be a major risk factor for both staff and patients who visit the facility (Krajewska et al. [20]). There are various pollutants in buildings which include $\mathrm{CO} 2, \mathrm{CO}, \mathrm{NO} 2, \mathrm{O} 3, \mathrm{HCHO}, \mathrm{TVOC}$, respirable suspended particulates, radon and bacteria (Kabir et al. [19] and [28]). These can adversely affect our health ranging from the sick building syndrome to Building Related Illnesses (BRI) such as pneumonitis and cancer at various degrees of severity. However, the risk is $2-20$ times higher in developing countries and the proportion of affected patients in those countries can exceed 25\%. Even though the respective managements are in the process of considering improvements, many healthcare establishments, particularly in the developing countries, are unable to achieve adequate levels of prevention (Pruss et al. [35]). A building and 
its ventilation may cause employees to suffer from adverse health effects.

A detailed study was done at the Hong Kong University regarding the role played by ventilation in the healthcare units in the airborne transmission of infectious agents and the study has concluded that there is a relationship between ventilation and the spread of infectious diseases [29]. Ventilation can also spread airborne pathogens when it is not properly maintained (Menzies et al. [23]). In some cases, the ventilation system can decrease the percentage of infections (Friberg et al. [17]). Hence, the provision of clean filtered air and the effective control of indoor air pollution are two key methods of maintaining good air quality that will help to mitigate HAIs.

\section{Research Methodology \\ 3.1 Study Design}

The research was initiated with a literature synthesis to identify common issues relating to IAQ and HAIs. Case study approach was adopted as the best method for the research which has to examine the existing phenomenon within a real life context especially when the boundaries between the phenomenon and the context are not clearly evident [12].

\subsection{Data Collection}

Yin [12] has mentioned that by identifying the unit of analysis, the researcher can fix the boundary of the study that will help the researcher to identify the scope of the study including the limits of data collection. It can be an individual person or an event or a team or a department within an organization [25]. In order to achieve the main aim of the research, the unit of analysis was selected as the healthcare sector whereas the scope was limited to private healthcare facilities because people believe that more secured treatment of higher quality is provided in these healthcare facilities compared to the public sector. However, HAIs create a huge impact on both the patient and the healthcare facilities such as increased medical bills, longer stays and unnecessary resource usage. Thus, this study will particularly be relevant to the private healthcare facilities.

According to Yin [12], the number of cases that have to be selected will depend on the nature of the research and the author's preference to multiple-case design over single-case design. Ramanathan [10] has stated that when the study area is too broad in a qualitative research, it is advisable to use a minimum of two extremes of four cases. However, since there is no precise guide on the number of cases to be considered, the number of cases used in this research was limited to three.

The selection of three cases was done to increase the reliability and limit the scope of the research considering the time constraints faced. This study was carried out on the private healthcare facilities in Sri Lanka especially on those in the Colombo District that have intensive care units, emergency care units, cardio thoracic units, kidney care centers, fertility centers, mother and baby care centers, diagnostic units, cosmetic centers and critical care units along with the provision of general surgery services. There are 14 healthcare facilities within the Colombo District, out of which only 8 come under the private sector. Out of these 8 private healthcare facilities also, only 3 were found to provide all of the above mentioned services. Hence, only these three cases were selected for the research.

\subsection{Case Study Design and Semi - structured Interviews}

Semi-structured interviews and document review were identified as the two best modes for gathering information. Semi-structured interviews assist to elicit elaborative and purposeful answers from respondents enabling clarification of doubts and ensuring that the response is properly understood by the interviewer by allowing for the repetition and rephrasing of the questions. Klenke [6] explained that semi-structured interviews reduce bias and irrelevant replies through follow up questions which offer flexibility to the researcher.

The interviews were conducted among experienced professionals in the industry. The number and type of respondents selected from each case were same, i.e., a chief engineer, a mechanical engineer and an infection controller. There were two interviewees from the engineering department and one from the infection control unit. Further details of the respondents' designations and years of experience are given in Table 1. Engineers and infection controllers were selected as they are professionals who are experts in IAQ and HAIs. Altogether, six engineers and three infection controllers/consultant microbiologists were considered for the semi-structured interviews. Respondents were requested to answer structured questions and during the interviews situational questions were also put to them. 
Documentary evidence helps to cross validate information gathered from interviews and observations, since sometimes what people say can be different from what they actually do [30]. Hence, a document review was carried out to validate the data collected through the interviews.

Table 1 - Interviewee details

\begin{tabular}{|l|l|l|l|}
\hline Code & Designation & $\begin{array}{l}\text { Location of } \\
\text { work }\end{array}$ & Experience \\
\hline \multicolumn{4}{|c|}{ Case A } \\
\hline A-01 & Chief Engineer & $\begin{array}{l}\text { Engineering } \\
\text { Department }\end{array}$ & 20 years \\
\hline A-02 & $\begin{array}{l}\text { Mechanical } \\
\text { Engineer }\end{array}$ & $\begin{array}{l}\text { Engineering } \\
\text { Department }\end{array}$ & 15 years \\
\hline A-03 & $\begin{array}{l}\text { Infection } \\
\text { Microbiologist }\end{array}$ & $\begin{array}{l}\text { Infection } \\
\text { Control Unit }\end{array}$ & 20 years \\
\hline \multicolumn{5}{|l|}{ Case B } \\
\hline B-01 & Group Engineer & $\begin{array}{l}\text { Maintenance } \\
\text { Division }\end{array}$ & 12 Years \\
\hline B-02 & $\begin{array}{l}\text { Assistant } \\
\text { Engineer }\end{array}$ & $\begin{array}{l}\text { Maintenance } \\
\text { Division }\end{array}$ & 15 Years \\
\hline B-03 & $\begin{array}{l}\text { Infection Control } \\
\text { Head }\end{array}$ & $\begin{array}{l}\text { Infection } \\
\text { Control Unit }\end{array}$ & 13 Years \\
\hline \multicolumn{5}{|l|}{ Case C } \\
\hline C-01 & $\begin{array}{l}\text { Mechanical } \\
\text { Engineer }\end{array}$ & $\begin{array}{l}\text { Engineering } \\
\text { Department }\end{array}$ & 15 Years \\
\hline C-02 & $\begin{array}{l}\text { Medical } \\
\text { Superintendent }\end{array}$ & $\begin{array}{l}\text { Engineering } \\
\text { Department }\end{array}$ & 13 Years \\
\hline C-03 & $\begin{array}{l}\text { Infection } \\
\text { Controller }\end{array}$ & $\begin{array}{l}\text { Infection } \\
\text { Control } \\
\text { Department }\end{array}$ & 09 Years \\
\hline
\end{tabular}

\subsection{Expert Validation}

In order to arrive at a better conclusion by validating the findings of semi-structured interviews, interviews were conducted among four experts who had specialized knowledge on the subject matter concerned. The details of the expert interviewees are given in Table 2.

Table 2 - Expert interviewee details

\begin{tabular}{|c|l|l|l|}
\hline Code & Designation & $\begin{array}{l}\text { Location of } \\
\text { work }\end{array}$ & Experience \\
\hline E-01 & $\begin{array}{l}\text { Consultant } \\
\text { Microbiologist }\end{array}$ & $\begin{array}{l}\text { Hospital; } \\
\text { Member of the } \\
\text { Sri Lanka } \\
\text { College of } \\
\text { Microbiologists }\end{array}$ & 16 Years \\
\hline E-02 & $\begin{array}{l}\text { Consultant } \\
\text { Microbiologist } \\
\& \text { Senior } \\
\text { Lecturer }\end{array}$ & $\begin{array}{l}\text { University } \\
\text { Senior Lecturer } \\
\text { - Medical } \\
\text { Science }\end{array}$ & 15 Years \\
\hline E-03 & $\begin{array}{l}\text { Microbiologist } \\
\text { Consultant }\end{array}$ & $\begin{array}{l}\text { University } \\
\text { Senior Lecturer } \\
\text { - Medical } \\
\text { Science; } \\
\text { Member of the } \\
\text { Sri Lanka } \\
\text { College of }\end{array}$ & 17 Years \\
\hline
\end{tabular}

\begin{tabular}{|c|l|l|l|}
\hline Code & Designation & \multicolumn{1}{|c|}{$\begin{array}{c}\text { Location of } \\
\text { work }\end{array}$} & Experience \\
\hline E-04 & $\begin{array}{l}\text { Communicabl } \\
\text { e Diseases } \\
\text { Unit }\end{array}$ & $\begin{array}{l}\text { Health } \\
\text { Organization }\end{array}$ & 18 Years \\
\hline
\end{tabular}

\section{Findings and Data Analysis}

4.1 Importance of Indoor Air Quality

A proper IAQ is important in healthcare facilities. The respondents identified the provision of thermal comfort and safety to the patient; provision of a safe and clean environment; reduction of the spread of infections; speedy recovery of the patient; effective running of the functions of the healthcare facility; control of infections; and prevention of contamination as reasons that signify the importance of IAQ in a healthcare facility. The respondents also declared that IAQ is one of the most important requirements in healthcare and that all need to adhere to it in order to provide a quality service to the patients. They also mentioned that IAQ when not properly maintained is often referred to as the sleeping giant of the building.

\subsection{Sources Affecting Indoor Air Quality}

Through the literature review and semistructured interviews, sources which affect IAQ were identified. The findings are illustrated in Table 3. These sources vary from building to building depending on the function of the building.

The sources identified from the literature were validated by the interviewees and several additional sources were also included by a few interviewees such as the exterior of the buildings, infected patients and high population. Interviewee B-02 opined that apart from the sources already mentioned under the category 'Outside the building' as affecting the indoor air quality, the exterior of the buildings also will matter. Interviewee B-01 added that the use of asbestos has to be highly restricted within and outside healthcare facilities as asbestos contaminates indoor air causing air borne infections which finally lead to HAIs. Interviewees A-01 and C-02 opined that infected patients need to be included separately under the category 'Human activities' as contagious diseases will spread very fast if IAQ is not maintained properly. Similarly, high population was added by Interviewees B-02 and C-01 under 'Human activities' as in their opinion, IAQ can get affected when the number of patients and occupants within the health facility increases. 
Table 3 - Sources affecting indoor air quality

\begin{tabular}{|c|c|c|c|c|c|c|c|c|c|c|c|}
\hline \multicolumn{2}{|c|}{ Sources from Literature } & \multirow[t]{3}{*}{ Reference } & \multicolumn{9}{|c|}{ Validated from interviewees } \\
\hline \multirow[b]{2}{*}{ Category } & \multirow[b]{2}{*}{ Source } & & \multicolumn{3}{|c|}{ Case $\mathbf{A}$} & \multicolumn{3}{|c|}{ Case B } & \multicolumn{3}{|c|}{ Case C } \\
\hline & & & $\begin{array}{l}\text { A- } \\
01\end{array}$ & $\begin{array}{l}\text { A- } \\
02\end{array}$ & $\begin{array}{l}\text { A- } \\
03\end{array}$ & $\begin{array}{l}\text { B- } \\
01\end{array}$ & $\begin{array}{l}\text { B- } \\
02\end{array}$ & $\begin{array}{l}\text { B- } \\
03\end{array}$ & $\begin{array}{l}\mathrm{C}- \\
01\end{array}$ & $\begin{array}{l}\text { C- } \\
02\end{array}$ & $\begin{array}{l}\text { C- } \\
03\end{array}$ \\
\hline \multirow{4}{*}{$\begin{array}{l}\text { Outside the } \\
\text { building }\end{array}$} & Contaminated outdoor air & \multirow{4}{*}{$\begin{array}{l}\text { U.S. Environmental } \\
\text { Protection Agency } \\
{[11]}\end{array}$} & $\checkmark$ & $\checkmark$ & $\checkmark$ & $\checkmark$ & $\checkmark$ & $\checkmark$ & $\checkmark$ & $\checkmark$ & $\checkmark$ \\
\hline & Emissions from nearby sources & & $\checkmark$ & $\checkmark$ & $\checkmark$ & $\checkmark$ & $\checkmark$ & $\checkmark$ & $\checkmark$ & $\checkmark$ & $\checkmark$ \\
\hline & Soil gas & & & $\checkmark$ & & $\checkmark$ & $\checkmark$ & & $\checkmark$ & & $\checkmark$ \\
\hline & Moisture/ standing water & & $\checkmark$ & $\checkmark$ & & $\checkmark$ & & $\sqrt{ }$ & $\checkmark$ & 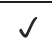 & $\checkmark$ \\
\hline \multirow{3}{*}{$\begin{array}{l}\text { Human } \\
\text { activities }\end{array}$} & Personal activities & \multirow[t]{3}{*}{ Levin [8] } & $\checkmark$ & $\checkmark$ & $\checkmark$ & $\checkmark$ & $\checkmark$ & $\checkmark$ & $\checkmark$ & $\checkmark$ & $\checkmark$ \\
\hline & Housekeeping activities & & $\checkmark$ & $\checkmark$ & $\checkmark$ & $\checkmark$ & $\checkmark$ & $\checkmark$ & $\checkmark$ & $\checkmark$ & $\checkmark$ \\
\hline & Maintenance activities & & $\checkmark$ & $\checkmark$ & $\checkmark$ & $\checkmark$ & $\checkmark$ & $\sqrt{ }$ & $\checkmark$ & $\sqrt{ }$ & $\checkmark$ \\
\hline \multirow[t]{2}{*}{ Equipment } & HVAC system & \multirow{2}{*}{$\begin{array}{l}\text { U.S. Environmental } \\
\text { Protection Agency } \\
\text { [11] }\end{array}$} & $\checkmark$ & $\checkmark$ & $\checkmark$ & $\checkmark$ & $\checkmark$ & $\checkmark$ & $\checkmark$ & $\checkmark$ & $\checkmark$ \\
\hline & Non-HVAC equipment & & $\checkmark$ & $\checkmark$ & $\checkmark$ & $\checkmark$ & $\checkmark$ & $\checkmark$ & $\checkmark$ & $\checkmark$ & $\checkmark$ \\
\hline \multirow{3}{*}{$\begin{array}{l}\text { Building } \\
\text { components } \\
\text { and } \\
\text { furnishing }\end{array}$} & $\begin{array}{l}\text { Locations that produce dust/ } \\
\text { fibers }\end{array}$ & \multirow[t]{3}{*}{ Levin [8] } & $\checkmark$ & $\checkmark$ & $\checkmark$ & $\checkmark$ & $\checkmark$ & $\checkmark$ & $\checkmark$ & $\checkmark$ & $\checkmark$ \\
\hline & $\begin{array}{l}\text { Unsanitary conditions and } \\
\text { water damage }\end{array}$ & & $\checkmark$ & $\checkmark$ & $\checkmark$ & $\checkmark$ & $\checkmark$ & $\checkmark$ & $\checkmark$ & $\checkmark$ & $\checkmark$ \\
\hline & $\begin{array}{lcr}\begin{array}{l}\text { Chemicals } \\
\text { building }\end{array} & \text { coming } & \text { from } \\
\text { furnishings } & & \\
\end{array}$ & & $\checkmark$ & $\checkmark$ & $\checkmark$ & $\checkmark$ & $\checkmark$ & $\checkmark$ & $\checkmark$ & $\checkmark$ & $\checkmark$ \\
\hline \multirow[t]{3}{*}{ Other factors } & Accidental events & \multirow{3}{*}{$\begin{array}{l}\text { U.S. Environmental } \\
\text { Protection Agency } \\
{[11]}\end{array}$} & & $\checkmark$ & $\checkmark$ & $\checkmark$ & & $\checkmark$ & & & $\checkmark$ \\
\hline & Special use areas & & & & $\checkmark$ & & $\checkmark$ & $\checkmark$ & &  & $\checkmark$ \\
\hline & $\begin{array}{l}\text { Redecoration } \\
\text { remodeling/ repair }\end{array}$ & & $\checkmark$ & $\checkmark$ & $\checkmark$ & $\checkmark$ & $\checkmark$ & $\checkmark$ & $\checkmark$ & $\checkmark$ & $\checkmark$ \\
\hline
\end{tabular}

However, each healthcare facility takes necessary precautions to ensure and maintain IAQ at a high standard. The respondents were of the view that the chemicals used in housekeeping were non-toxic to the environment. Hence according to their experience, these chemicals cannot be considered as a source affecting IAQ. They highly recommended material such as antistatic vinyl flooring and anti-fungal paint to safeguard the IAQ of healthcare facilities.

\subsection{Causes of Hospital Acquired Infections}

HAIs taken together are an important aspect which relates to infections that spread every day during the functioning of a healthcare facility. Previous researchers have identified several causes such as inadequate ventilation, malfunctioning systems and administrative controls as root causes of HAIs. All of the interviewees agreed with these causes and mentioned few other causes such as improper maintenance of air conditioning systems, poor hand hygiene, disinfectants, failure to follow certain procedures, age and health of the patients, type of treatment provided, poor sterilization of medical equipment, poor housekeeping, excessive number of visitors and the absence of awareness on the subject among staff and their lack of training as leading to improper indoor air management and HAIs. Ventilation plays a major role because nowadays all healthcare facilities are ventilated using mechanical ventilation systems. Hand hygiene is another important mode of spreading infections which needs attention. Age and the status of health of the patient and the treatment provided by the healthcare facility also can vary from patient to patient and this factor too needs to be given consideration when considering infections. The level of immunity of a patient can also vary depending on his/her capacity. Therefore, different procedures need to be followed by healthcare facilities to mitigate HAIs based on the body conditions of the patients.

\subsection{Impacts of Hospital Acquired Infections}

A HAI is an illness common in the healthcare sector. HAIs not only affect the general health of the patients but also increase the financial burden on both the patients and the healthcare facility. Their foremost impact is on the medical costs that the patients and the healthcare facility have to bear, because an infected patient needs to stay longer in the healthcare facility than expected requiring increased resources such as man power and space to treat the infected patient. HAIs can lead to long and short term disability of the patient even leading at times to the death of the patient. 


\section{5}

\section{Statistics of Hospital Acquired} Infections

A document review was carried out to collect information on the statistics on HAIs. As already mentioned, documentary evidence generally acts as a method to cross validate information gathered from interviews and observations since at times what people say may differ from what they actually do. Thus, this technique was used in this research to gather statistics about HAIs in the healthcare sector as the aim of this research was to identify the relationship between IAQ and HAIs. Hence, the document review was used to validate the data gathered from semi-structured interviews. In order to collect statistical data, the documents which were available in infection control units were analysed. Figure 1 given below depicts the infection rate of selected cases.

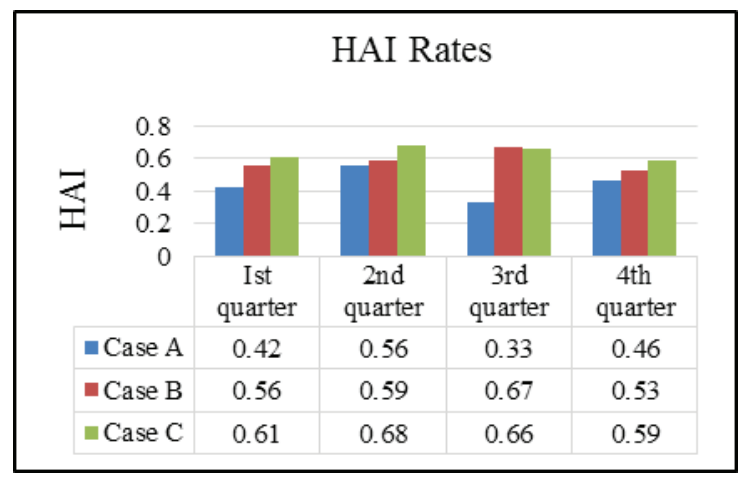

Figure 1 - HAI rates

Case A has a considerably low number of infections since proper procedures both in respect of engineering and infection control measures that are being practiced have mitigated the spread of infections.

\subsection{Strategies to Mitigate HAIs in Healthcare Facilities}

The semi-structured interviews assisted in identifying the existing strategies that are used in the respective healthcare facilities in order to mitigate HAIs through the provision of better IAQ. As a result, engineering strategies and infection control strategies currently being implemented at the selected healthcare facilities were read out and the respondents were requested to propose any other suitable strategies to mitigate HAIs. The resulting findings are illustrated in Table 4.
Table 4 - Strategies to mitigate HAIs in healthcare facilities

\begin{tabular}{|c|c|c|}
\hline \multicolumn{2}{|c|}{ Existing Strategies } & \multirow[b]{2}{*}{ Proposed Strategies } \\
\hline $\begin{array}{l}\text { Engineering } \\
\text { Strategies }\end{array}$ & $\begin{array}{l}\text { Infection } \\
\text { Control } \\
\text { Strategies }\end{array}$ & \\
\hline $\begin{array}{l}\text { Mechanical } \\
\text { Ventilation }\end{array}$ & $\begin{array}{l}\text { Infection } \\
\text { Control Unit }\end{array}$ & IAQ Committee \\
\hline Filtration & IAQ Audit & $\begin{array}{l}\text { Sensors to Monitor } \\
\text { IAQ Parameters, } \\
\text { Awareness taring for } \\
\text { operators, Accounting } \\
\text { cost of filters }\end{array}$ \\
\hline $\begin{array}{l}\text { Proper } \\
\text { Preventive } \\
\text { Maintenance }\end{array}$ & HAI Audit & $\begin{array}{l}\text { Building Management } \\
\text { System, Maintain a log } \\
\text { of DP of filter bank, } \\
\text { Replacing filters at } \\
\text { correct interval }\end{array}$ \\
\hline Dilution & $\begin{array}{l}\text { Proper } \\
\text { training of } \\
\text { nurses }\end{array}$ & $\begin{array}{l}\text { Continuous } \\
\text { Monitoring of the } \\
\text { Practices }\end{array}$ \\
\hline Isolation Room & $\begin{array}{l}\text { Infection } \\
\text { Control } \\
\text { Committee }\end{array}$ & $\begin{array}{l}\text { Awareness to Nurses, } \\
\text { Patients and Visitors }\end{array}$ \\
\hline $\begin{array}{l}\text { Laminar Air } \\
\text { Flow in } \\
\text { Operating } \\
\text { Theatre }\end{array}$ & $\begin{array}{l}\text { Awareness } \\
\text { to patients }\end{array}$ & $\begin{array}{l}\text { HAI Audit should be } \\
\text { carried out by Outside } \\
\text { Parties }\end{array}$ \\
\hline Record Keeping & $\begin{array}{l}\text { Vaccination } \\
\text { of patients } \\
\text { and staff }\end{array}$ & $\begin{array}{l}\text { UV System in the } \\
\text { Central Air Handler }\end{array}$ \\
\hline $\begin{array}{l}\text { Pressurization } \\
\text { Control }\end{array}$ & & $\begin{array}{l}\text { Limit the Number of } \\
\text { Visitors to the } \\
\text { Hospital }\end{array}$ \\
\hline $\begin{array}{l}\text { Check IAQ } \\
\text { from Outside } \\
\text { Parties }\end{array}$ & & $\begin{array}{l}\text { Height of the } \\
\text { Chimney }\end{array}$ \\
\hline $\begin{array}{l}\text { Proper } \\
\text { Housekeeping } \\
\text { Practices }\end{array}$ & & \\
\hline $\begin{array}{l}\text { Construction } \\
\text { and Renovation }\end{array}$ & & \\
\hline
\end{tabular}

The respondents from engineering/ maintenance departments and infection control units indicated the various engineering strategies that are being practiced at their respective healthcare facilities. They were of the view that ventilation and dilution play a major role in preventing diseases from spreading. Therefore according to them, the HVAC has to provide healthy air for breathing by removing and diluting the pollutants originating from within the building. Similarly, filtration allows for the physical removal of particulates from the air and it is the first step in achieving an acceptable IAQ. In Sri Lanka, most of the hospitals do not have a proper filtration strategy in the Operating Theatres (OT), Intensive Care Units (ICU) and other critical care areas. Even if there is proper equipment, 
their poor maintenance can cause a considerable threat as far as HAIs are concerned. It has been found that the minimum required filtration is not provided, which causes the spread of diseases. There are no proper equipment to ascertain filter saturation and discard them safely.

Some of the proposed technical strategies are:

1. Avoiding the use of water-cooled systems and water cooling towers to reduce $L D$,

2. Providing at least a 3-filter system with HEPA filter on the terminals of all operating theatres,

3. Providing deferential pressure gauges with alarms in all high efficiency filter sections, and

4. Maintaining the fresh air extract outlets at the required distance to comply with

ASHRAE 62.1.

On the other hand, the isolation room assists in avoiding the spreading of communicable diseases.

Various infection control strategies were being practiced by the selected healthcare facilities to mitigate HAIs. The establishment of an infection control unit has considerably assisted in monitoring and controlling HAIs in healthcare facilities. IAQ audits and HAI audits are conducted internally to ensure that the healthcare facility concerned is maintaining the required quality and standard to provide a better service to its patients and visitors.

A number of strategies were further proposed by the respondents to mitigate HAIs through IAQ. According to them, the establishment of an IAQ committee comprising of responsible parties from the engineering department and the infection control unit can create a better understanding of the relationship between IAQ and HAIs. Installation of sensors at various locations to monitor IAQ parameters will assist in-house staff in knowing the variations within the day and accordingly a system can be developed to control the air flow at each location to maintain a proper IAQ within the building. Implementation of a building management system to maintain and improve the IAQ was also proposed to monitor the entire building with the assistance of intelligent software.

Subsequently, interviews were conducted among four experts who had expertise in the subject matter concerned, in order to validate the identified strategies and to increase the reliability and validity of the data collected through the semi-structured interviews and document review. The experts agreed on all the strategies practiced in healthcare facilities and also on the proposed strategies that will mitigate HAIs through a better IAQ. The experts added a few more strategies such as hand washing, avoidance of overcrowding, usage of face masks, following of Standard Operating Procedures (SOPs) along with other relevant standards and guidelines and continuous education of staff as suitable strategies to mitigate HAIs.

\subsection{Proposed Framework to Mitigate HAIs through the Provision of a Better IAQ}

From the literature study, six strategies namely, ventilation and dilution; filtration; pressurization control; isolation room; proper maintenance of HVAC and laminar air flow were identified. However, from the semistructured interviews, it was possible to identify new strategies other than those that were identified from the literature study and they could be subdivided as engineering strategies and infection control strategies. The strategies that were identified from the three selected cases were also combined and compared with one another. As a result, the most suitable strategies that need to be implemented in healthcare facilities were identified for mitigating HAIs by improving IAQ. The selected strategies were cross validated by experts' opinions and the framework illustrated in Figure 2 was developed. 


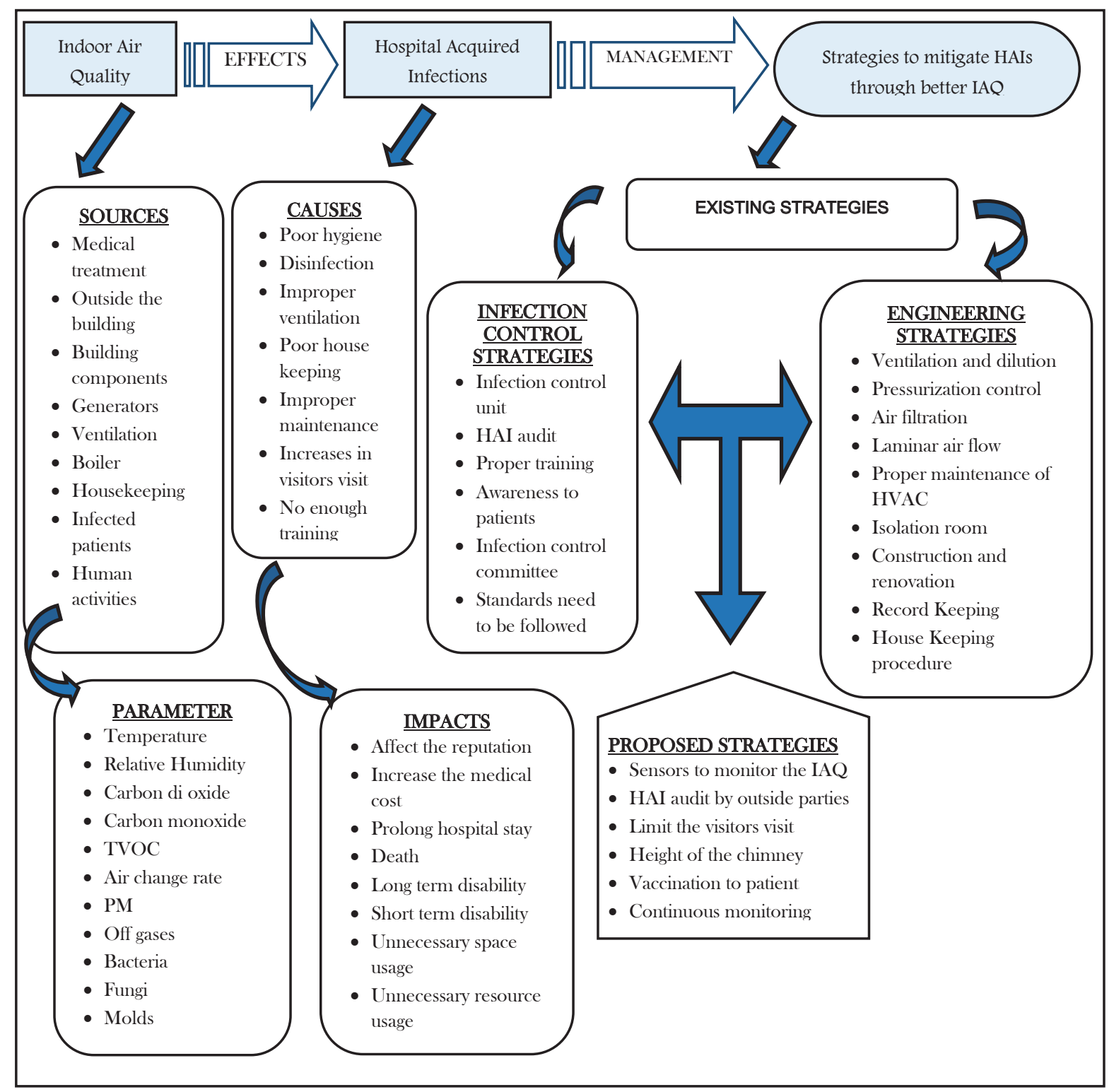

Figure 2 - Proposed Framework

\section{Conclusions}

Air is one of the major requirements for human wellbeing and all buildings have now moved from natural ventilation to mechanical ventilation. Healthcare facilities face numerous challenges when providing quality air within their buildings since most of the air inside the buildings is highly contaminated. Thus, infections are unexceptionally high within healthcare facilities and various mitigation steps are taken by each healthcare facility to decrease the infection rate.

The phenomenon of HAIs highly affects the reputation of a healthcare facility. Therefore, at the outset, the main sources which contribute to infections in healthcare facilities were identified. The causes of HAIs and their impact on the healthcare facilities were also recognized. Subsequently through the study, 30 strategies that will mitigate HAIs were identified and they included laminar air flow for the operation rooms, an isolation room to treat infected patients, proper maintenance of ventilation systems and practice of safe hand hygiene. However, several barriers in implementing these procedures such as the absence of consultants in the field, financial constraints, management issues, lack of awareness among staff and poor training of staff were found. Hence, this proposed framework is a recommendation to enable engineers, facility managers and infection controllers working in healthcare facilities to provide a service of high standard to the patients who seek treatment in their respective healthcare facilities. 


\section{References}

1. American Institute of Architects (AIA), Guidelines for Design and Construction of Hospitals and Healthcare Facilities, The American Institute of Architects press, Washington, 2001.

2. ASHRAE. Ventilation for acceptable indoor air quality standard 62.1, Author, United States of America, 2007.

3. ASHRAE, Indoor Air Quality Guide: Best Practices for Design, Construction, and Commissioning, W. Stephen Comstock, United States of America, 2009.

4. Center for Disease Control and Prevention [CDC] and Healthcare Infection Control Practices Advisory Committee. Guidelines for Environmental Infection Control in Health-Care Facilities, Department of Health and Human Services, Atlanta, 2003.

5. Ducel, G., Fabry, J., \& Nicolle, L., Prevention of hospital-acquired infections: A practical guide, WHO, UK, 2002.

6. Klenke, K., Qualitative Research in the Study of Leadership, Emerald Group Publishing, UK, 2008.

7. Kubba, S., Handbook of Green Building Design and Construction: LEED, BREEAM, and Green globes. Butterworth Heinemann, United States of America, 2012.

8. Levin, H., Commercial Building Indoor Air Quality: An Introduction to the Problem, Northeast Energy Efficiency Partnerships Inc, Lexington, 1999.

9. Pahwa, D., Health and Indoor Air Quality- A Growing Concern, Meditech, Bombay, 1995.

10. Ramanathan, T. R., The Role of Organizational Change Management in Offshore Outsourcing of Information Technology Services, Universal Publishers, Florida, 2008.

11. U.S. Environmental Protection Agency, Building air Quality Guide for Owners and Facility Manager, NIOSH, Washington, DC, 1991.

12. Yin, R. K., Case Study Research: Design and Methods, $4^{\text {th }}$ ed, Sage Publications, California, 2009.

13. Anon, "Office Air Quality", Facilities, Vol. 02, No.10, 1984, pp. 4-7.

14. Bernstein A. J., Alexis, N., \& Bacchus, H., "The Health Effects of Non-Industrial Indoor Air Pollution", The Journal of Allergy and Clinical Immunology, Vol. 121, No. 03, 2008, pp. 589-591.
15. Cheong, W. K., \& Chong, Y. K., “Development and Application of an Indoor Air Quality Audit to an Air Conditioned Building in Singapore", Building and Environment, Vol. 36, No. 02, 2001, pp. 181-188.

16. Codinhoto, R., Tzortzopoulos, P., Kagioglou, M., \& Aouad, G., Cooper, R., "The Impacts of the Built Environment on Health Outcomes", Facilities, Vol. 27, No. 03, 2009, pp. 138-151.

17. Friberg, S., Ardnor, B., Lundholm, R., \& Friberg, B., "The Addition of a Mobile Ultraclean Exponential Laminar Airflow Screen to Conventional Operating Room Ventilation Reduces Bacterial Contamination to Operating Box Levels", Journal of Hospital Infection, Vol. 55, No. 02, 2003, pp. 92-97.

18. Inweregbu, K., Dave, J., \& Pittard, A., "Noscomial Infections", Oxford journal, Vol. 05, No. 01, 2005, pp. 14-17.

19. Kabir, E., Kim, H. K., Sohn, R. J., Kweon, Y. B., \& Shin, H. J., "Indoor Air Quality Assessment in Child Care and Medical Facilities in Korea", Environmental Monitoring and Assessment, Vol. 184, No. 10, 2012, pp. 6395-6409.

20. Krajewska, E. K., Lukaszuk, C., \& Tsokantaridis, C., "Indoor Air Studies of Fungi Contamination at the Neonatal Department and Intensive Care Unit an Palliative Care in Kavala Hospital in Greece", Advance Medical Science,Vol. 52, 2007, pp. $11-14$

21. Lawrence, D., Jayabal, S., \& Rajmohan, B., “Study and Analysis of Indoor Air Quality Characteristics on Air Conditioned Application in Hospital Room", International Journal of Engineering Research \& Technology, Vol. 03, No. 09, 2014, pp. 720-724.

22. Liyanage, C., \& Egbu, C., "Controlling Healthcare Associated Infections (HAI) and the Role of Facilities Management in Achieving Quality in Healthcare: A Three-Dimensional View", Facilities, Vol. 23, No. 05, 2005, pp. 194-215.

23. Menzies, D., Fanning, A., Yuan, L., \& Fitzgerald, M. J., Hospital Ventilation and Risk for Tuberculosis Infection in Canadian health care workers, Canadian Collaborative Group in Nosocomial Transmission of TB: Annals of Internal Medicine, Vol. 133, No. 10, 2000, pp. 779-789.

24. Paula, R. C., Krebs, L. V., \& Auler, E. M., "Nosocomial Infection in Newborns by Pichia Anomala in a Brazilian Intensive Care Unit", Medical Mycolody, Vol. 44, No. 05, 2006, pp. 479484 .

25. Rowley, J., "Using Case Studies in Research", Management Research News, Vol. 25, No. 01, 2002, pp. 16-27. 
26. Tellier, R., “Aerosol Transmission of Influenza : A Virus: A Review of New Studies", Journal of the Royal Society Interface, Vol. 06, 2009, pp. 783-790.

27. Vedanthan, R., Seligman, B., \& Fuster, V., “Global Perspective on Acute Coronary Syndrome A Burden on the Young and Poor", American Heart Association Journals, Vol. 114, 2014, pp. 1959-1975.

28. Wong, S. K., Lai, L. W. C., Ho, D. C. W., Wing, C. K., Lam, C. L. K., \& Ng, C. H. F., “Sick Building Syndrome and Perceived Indoor Environmental Quality: A Survey of Apartment Buildings in Hong Kong", Habitat International, Vol. 33, No. 04, 2009, pp. 463-471.

29. Yu, I. T., Li, Y., Wong, T. W., Tam, W., Chan, A. T., Lee, J. H., Ho, T., "Evidence of Airborne Transmission of the Severe Acute Respiratory Syndrome Virus", The New England Journal of Medicine, Vol. 350, No. 17, 2004, pp. 1731-1739.

30. Bandula, K. A., Analysing Costs and Beneftis of Transport Infrastructure Project: A Case Study on Hambantota International Airport (Unpublished Undergraduate Disseratation), University of Moratuwa, Sri Lanka, 2012.

31. Celik, G. B., Decision Model to Optimize Indoor Air Quality in Commercial Building in Florida (Doctoral dissertation), University of Florida, Florida, 2006.

32. European Medical Hygiene [EMH], Healthcare Associated Infection Control, 2013, http:/ / www.emhmagazine.com/article.php?arti cle_id=844, Visited, 30 ${ }^{\text {th }}$ May 2015.

33. Hughes, M., \& Hafen, R. M., Sick Again Older Patients Suffer Post Hospital Syndrome, 2013, http://vitals.nbcnews.com/_news/2013/01/09/ 16433847, Visited, 8th July 2015.

34. International Facility Management Association, Air Filter Provide Primary line of Defense, 2012, http:/www.facilitymanagement.com/article/hva c-2012-12_01.html, Visited, 10 th June 2015.

35. Pruss, A., Giroult, E., \& Rushbrook, P., Safe Management of Wastes from Healthcare Activities, 1999, http://www.who.int/water_sanitation_health/ medicalwaste/148to158.pdf, Visited, 2nd May 2015.

36. Ramasamy, M., Jahwari, A. F., \& Rajhi, S. M. M. A., IAQ in Hospitals: Better Health through Indoor Air Quality Awareness, In Proceedings of the Tenth International Conference Enhanced Building Operations, 2010, http://www.researchgate.net/publication/50835 672, Visited, 28 th August 2015. 